\title{
Spatio-Temporal Evolution Mechanism and Influence Factors of the China's Characteristic Town Policy and Diffusion
}

\author{
Hongmei Liu \\ School of Public Management, South China Agricultural University, Guangzhou, China \\ Email: alice_mmliu@163.com
}

How to cite this paper: Liu, H. M. (2020). Spatio-Temporal Evolution Mechanism and Influence Factors of the China's Characteristic Town Policy and Diffusion. Open Journal of Social Sciences, 8, 328-340.

https://doi.org/10.4236/jss.2020.87026

Received: July 14, 2020

Accepted: July 26, 2020

Published: July 29, 2020

Copyright $\odot 2020$ by author(s) and Scientific Research Publishing Inc. This work is licensed under the Creative Commons Attribution International License (CC BY 4.0).

http://creativecommons.org/licenses/by/4.0/

\begin{abstract}
The characteristic town policy plays a significant carrier of China's new urbanization construction and it spreads all over China in a rapid way based on the method of "absorption-radiation". Based on the perspective of policy diffusion theory, this paper analyzes the innovation and adoption characteristic town policy in 31 provincial administrative units and explores the influence factors of the characteristic town policy diffusion. The outcomes demonstrate that in the temporal dimension, the diffusion of the characteristic town policy among provincial governments is in line with the classic S-shaped cumulative distribution curve and the diffusion process can be grouped into three stages. In addition, in the spatial dimension, the characteristic town policy ranges from the central government to local government and from superior level to inferior level, showing a certain level of effect. In just three years after the policy was promulgated, 29 provincial governments have formulated construction plans for the characteristic towns, cultivating 403 national characteristic towns and more than 10,000 characteristic towns above the prefectural level. Besides, among the internal and external factors such as economic status, urbanization rate, area of jurisdiction and central pressure play a vital role in affecting the diffusion of characteristic town policy.
\end{abstract}

\section{Keywords}

Characteristic Town, Policy Diffusion, Spatio-Temporal Evolution, Factors

\section{Introduction}

In recent years, China has vigorously promoted the construction of new urbanization. However, some cities and towns blindly pursue urban scale, which is in- 
consistent with the local economic reality and in lack of industrial support, thus hindering the further development of cities and towns. In October 2014, when Li Qiang, the governor of Zhejiang province, visited the "Yunqi Town", he proposed the concept of "characteristic town" for the first time, positioning the "characteristic town" as an important carrier of industrial innovation in Zhejiang province. Since then, Zhejiang province begins to explore the integration development path of new urbanization and regional characteristic industry (Zhou, 2017). In April 2015, Zhejiang province issued the "Guiding Principals of the People's Government of Zhejiang Province on Accelerating the Planning and Construction of Characteristic Towns", in which a batch of characteristic towns will be built in next three years which embrace distinctive industrial features, flexible institutional mechanisms, strong cultural atmosphere, beautiful ecological environment, and multiple functions. Later, this policy was adopted by the central government and then was rapidly promoted throughout the China, achieving fruitful outcomes. Why did the characteristic town policy spread rapidly in China? What are the spatio-temporal features in the policy diffusion process? The issues emerged in the diffusion process remain unclear and need to be revealed further. From the perspective of policy diffusion, the paper studies the spatio-temporal evolution mechanism and affecting factors of characteristic town policy, in order to increase people's understanding of policy diffusion and provide references for optimizing the development of characteristic town policy.

\section{Analysis on the Spatio-Temporal Evolution Mechanism of the Characteristic Town Policy}

Chinese government websites are the most important platforms for promoting government information disclosure and interaction between the government and the people (Li \& Shang, 2020). This paper employs the portal web of the relevant central government departments and provincial and regional governments and analyzes the policies formulated by the central government and 31 provincial governments (except Hong Kong, Macau, and Taiwan) from 2015 to 2019 to build characteristic towns, In order to explore the innovative diffusion process of the characteristic town policy among Chinese provincial governments, the provincial government that formulated the characteristic town policy will be considered as governments having adopted the characteristic town policy.

\subsection{The Temporal Evolution of the Characteristic Town Policy: S-Type Diffusion}

The concept of characteristic towns, formed in 2014, was first implemented by Zhejiang Province in April 2015. In this year, another two provincial governments issued the policy text of the characteristic town in line with the province (autonomous region) features. From 2016 to 2017, the characteristic town policy was adopted in all-around way by the provincial governments.

By the end of 2017, 25 provincial governments had embraced the characteris- 
tic town policy, with an adoption rate of $80.6 \%$. As of the end of 2019, 29 out of the 31 provincial governments had formulated special town policy texts, with an adoption rate of $93.5 \%$. Figure 1 represents the cumulative changing curve of the number of policy documents over time formulated by the provincial governments at the end of the year. As it can be seen from the graph, the diffusion of characteristic town policies among provincial governments accords with the classic S-shaped cumulative distribution curve (Nicholson-Crotty, 2009), whose diffusion process can be divided into three stages.

1) The first stage: initial promotion stage of the policy (2014-2015)

Based on the concept of characteristic town put forward in 2014, Zhejiang Province conducted a pilot test on the characteristic town policies, and issued a regulatory policy text in April 2015 so as to carry out top-level design for the construction of characteristic towns. In October 2015, the first batch of 37 characteristic towns was published, among which the characteristic towns, with $\mathrm{Yu}$ huang Mountain South Fund Town, West Lake Yunqi Town, Yuhang Dream Town as representatives, began to come to the public attention. Inspired by the characteristic town policy launched in Zhejiang Province, the Tibet Autonomous Region issued the "Implementation Plan for the Construction of Demonstration Sites for Characteristic Towns in the Tibet Autonomous Region" in May 2015 to explore new urbanization roads with Chinese characteristics and Tibetan features. "Work Plan for the Construction of 100 Characteristic Industrial Towns in Hainan Province" to promote the construction of characteristic industrial towns. Generally speaking, there is lack of high-level policy demonstration or recognition at this stage, insufficient the policy basis. In addition, there is no agreement on the cultivation of characteristic towns reached by governments in all the provinces (autonomous regions), thus leading to the slow diffusion of characteristic town policies.

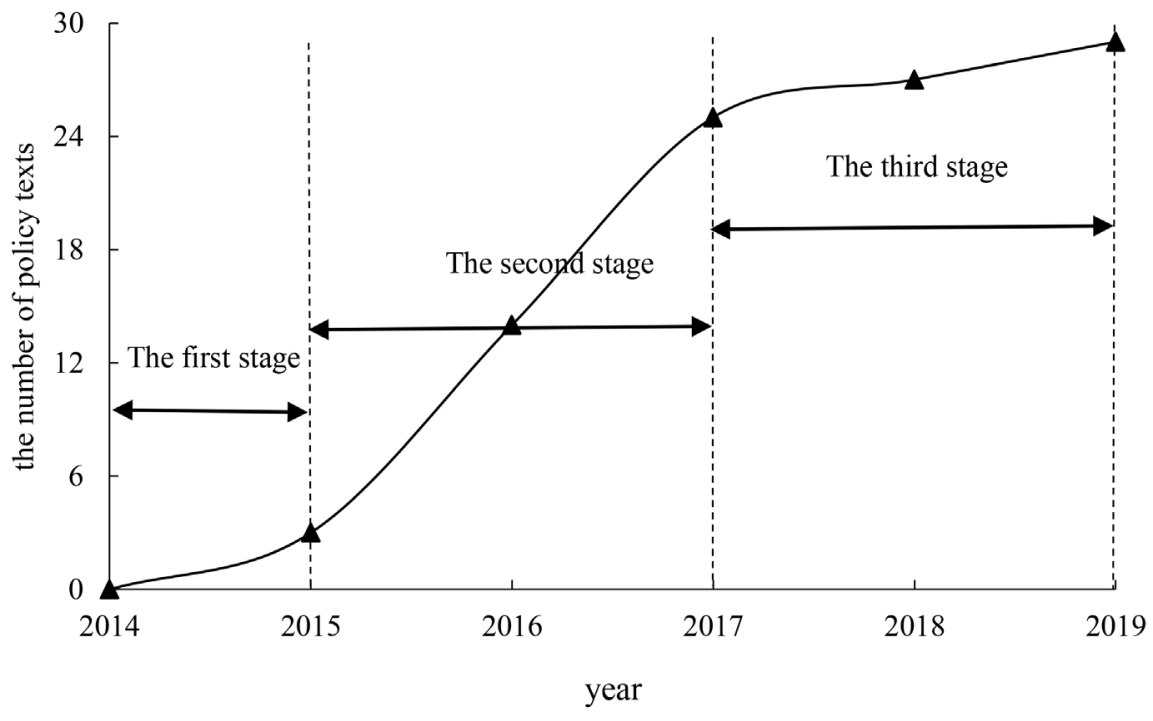

Figure 1. Cumulative chart of policy adoption for Characteristic Towns of provincial administrative units. Source: the portal websites of the provincial governments. 
2) The second stage: rapid diffusion period policy (2016-2017)

The successful demonstration of the Zhejiang characteristic town policy has attracted the attention of the central government. Therefore, General Secretary Xi Jinping and Premier Li Keqiang made important instructions on characteristic town in December 2015 to introduce the Zhejiang's experience to the whole country. In July 2016, the Ministry of Housing and Urban-Rural Development, National Development and Reform Commission and the Ministry of Finance jointly issued the Notice on the Development and Cultivation of Characteristic Towns, and in October 2016, the National Development and Reform Commission issued the Guiding Principals on Accelerating the Construction of Beautiful and Characteristic Towns.

Since then, the characteristic town policy has attracted the attention of the superior government, forming a policy system. Therefore, the top-level design has been carried out at the national level, especially the cultivation of around 1000 specific goals on the construction of characteristic towns in 2020 and rewards to characteristic towns with better performance granted by the central government. These above-mentioned measures have charted course for the provincial governments and solved future worries. Under the encouragement and guidance of the policy put forward by central government, the characteristic town policy has spread rapidly in all provinces (autonomous regions) across China. During the 2016 and 2017,there are 22 provinces (autonomous regions) adopted the characteristic town policy, accounting for $71.0 \%$ of the provinces (autonomous regions) nationwide, among which two batches of national-level characteristic towns (403).

3) The third stage: the late stage of policy diffusion (2018-2019)

After the second stage of rapid diffusion, only 6 provinces (autonomous regions) had not introduced policies related to characteristic towns by the end of 2017. Henan Province, Qinghai Province, Jilin Province, and Hunan Province also followed up in 2018 and 2019, with only the Shanxi Province and the Xinjiang Autonomous Region having not launched special town policy. Due to the high adoption rate in the early stage, the policy diffusion at this stage began to slow down and entered the late stage.

Although the characteristic town policy has been widely adopted, local governments have shown inaccuracy in upper-level policy and unclear decisionmaking in the process of policy making, thus resulting in homogenization and real estate tendency of some characteristic towns, contributing to "hollow towns" focusing on image project yet without any concrete contents and industry support. All impractical work confuses the concept of characteristic town and violates the original intention of the construction of characteristic town, making it difficult to achieve the strategic goal of promoting supply-side structural reform and industrial upgrading within a concentrated place How to deal with a characteristic town becoming a problem town? (Zhong Zheng Think Tank, 2019). The main reason for this phenomenon is that the so-called innovation of some 
local governments is actually a formal imitation instead of the study of policy connotation (Shang et al., 2018). In order to correct deviations in time, the central government issued the "Notice on Several Issues Regarding the Preservation and Demonstration of the Characteristics Towns", "Several Opinions on Standardizing the Promotion and the Construction of Characteristic Towns", and "Notice on the Establishment and High-quality Development Mechanism of Characteristic Towns", and established a elimination mechanism to slow down the construction of characteristic town.

\subsection{The Spatial Evolution of the Characteristic Town Policy: Proximity Effect and Hierarchy Effect}

From the spatial aspect, policy diffusion, affected by regional factors, usually has a certain gradient, shows interaction in both horizontal and vertical directions (Wang \& Pang, 2018). As for the characteristics town policy, the overall trend is that the policy gradually spread from the eastern area with developed economy to the central and western area in China.

1) Proximity effect (Weyland, 2005; Go, 2016)

Provincial governments work to reduce the cost of policy experiments by mutual learning. At the same time, due to the performance appraisal pressure from superior government, governments at the same level compete with each other to adopt and implement policies, which is horizontal mutual learning. The coexistence of mutual learning and parallel competition represents the main features of the proximity effect of China's public policy diffusion. Prior to July 2016, some early diffusion sources appears in terms of the characteristic town policy, mainly including Zhejiang province, Tibet autonomous region, Hainan province, Guizhou province, Fujian province, and Chongqing province. At this period of time, due to the lack of top-level design, those provinces learned from each other, and make innovations in characteristic town policy according to local conditions with the combination of their own circumstances. Among them, the the model in Zhejiang province has been selected by the central government as a pioneer in the characteristic town policy. It also set an example for other provinces and promoted the diffusion of the characteristic town policy. After the issuance of the "Notice on the Cultivation Work on Characteristic Town", policy diffusion demonstrated obvious proximity effects. First, neighboring eastern provinces such as Hebei province, Tianjin province, Shandong province, Jiangsu province, and Shanghai province share similar economic and social problems as Zhejiang province, making it easier to learn from the policy in Zhejiang province. With Zhejiang province as the example, the above-mentioned provinces learned and imitated the characteristic town policy in a rapid way. Meanwhile, when superior governments evaluates the implementation of policies, it is more likely that similar areas are put together for evaluation in a comparative way. Owing to pressure, provincial-level governments also tend to recreate policies to distinguish them from other provinces that have implemented characteristic 
town policies. As Jiangsu Province brought forward that "perseverance in cultivating characteristic towns in an innovation-oriented way with high standards", "perseverance in making policy according to local conditions and building distinctive towns", "perseverance in creating people-oriented town which is suitable for start-up, living and tourism", "perseverance in constructing a market-oriented town in a diverse way", "perseverance in saving land so as to improve land output benefit in an intensive way". Apart from that, the province also proposed classification methods to make characteristic town policies more specific and easier to implement, effectively avoiding such problems of characteristic town policy as serious homogenization and real estate tendency. Subsequently, the characteristic town policy gradually spread to central provinces such as Anhui, Hubei, and Jiangxi, and western provinces such as Gansu, Shaanxi, and Sichuan.

2) Hierarchy effect (Walker, 1969; Brown \& Cox, 1971)

Since China is a unitary country, superior level government has stronger binding force on inferior level government and has a higher degree of hierarchy (Zhu, 2014; Zhu \& Zhang, 2019; Zhang \& Zhu, 2018), leading to a top-down diffusion in the spreading process of characteristic town policy. The characteristic town policy originated from the Zhejiang Provincial Government. After the Zhejiang Provincial People's Government introduced the special town policy in 2015, prefectural governments in such cities as Taizhou, Shaoxing, Wenzhou, Jinhua, Hangzhou, Quzhou, Jiaxing and Ningbo have followed up the provincial government with the introduction of the characteristic town policy with the policy spreading from the provincial government to the prefectural governments. In 2016, the central government issued a national policy of characteristic town to spread the policy throughout China based on the summary of the experiences in Zhejiang province. In the national popularization process of the policy, the hierarchy effect is more obvious. The provincial governments adopt policies from central government, and then the eastern regions take the lead yet the central and western regions follow up. Prefectural governments issue characteristic town policies in accordance with national and provincial policies, and play a proactive role in applying for and organizing the cultivation of characteristic towns at municipal, provincial, and national level. The central has a strong appeal, which greatly enhances the diffusion capacity of characteristic towns with administrative orders. Governments at provincial, municipal, county, and town levels have in-depth learning and follow up from one level to another level to speed up implementation of characteristic town policy. In this connection, the characteristic town policy will be fully spread from top to bottom, from specific spots to entire areas and throughout China.

\section{Diffusion Factors of Characteristic Town Policy}

In the characteristic towns that have emerged as a result of China's new urbanization construction, the diffusion process embraces distinctive Chinese characteristics. How can the characteristic town policy be promoted to spread rapidly 
in China under the Chinese political environment? In order to further explore the influencing factors of the characteristic town policy, this paper divides the potential influencing factors into internal factors and external factors, and attempts to construct a reasonable theoretical framework to reveal the driving factors of the characteristic town policy diffusion under China's national conditions.

\subsection{Research Hypothesis}

\subsubsection{Internal Factors}

1) The economic and financial situation of local governments. The better the local economic situation is, the more complex the industrial structure will be. Local governments seek reforms through policy innovations in characteristic towns, further agglomerating resources, strengthening characteristic and advantageous industries and contributing to a stronger motivation to promote sustained and healthy economic development. The construction of characteristic towns is able to provide new impetus for the economic development of local governments while local governments tend to adopt policies to improve local economies and investment environments. In addition, the characteristic town policy represents a type of public policy, whose construction is jointly funded by the central government and local governments. Therefore, local governments with strong financial strength can provide more budget support and better implement the policy. On the contrary, when the financial situation of local government is not ideal, when formulating policy, policymakers will give priority to supporting the most urgent local issues and may not be able to take into account the characteristic town policy (Arbolino et al., 2018; Berry, 1994).

Hypothesis 1: The better the economy of a place is, the more likely it is to adopt a characteristic town policy.

Hypothesis 2: The better financial situation of a place is, the more likely it is to adopt the characteristic town policy.

2) The status of local government urbanization construction. Both the new urbanization strategy and the rural revitalization strategy take the characteristic town policy as an important starting point to further promote new urbanization, thereby facilitating the integration of urban and rural development. The lower urbanization development level of local governments is, the higher the political pressure of policy makers will be, who are more inclined to adopt policies to speed up urban construction. In addition, the construction of characteristic towns has stimulated the development of the real estate industry. The more developed the local government real estate industry is, it is more likely that the local governments will tend to adopt policies and continue to maintain the real estate industry development.

Hypothesis 3: The lower the urbanization rate of a place is, the more likely it is for local governments to adopt a characteristic town policy.

Hypothesis 4: The more developed a local property and real estate industry is, the more likely it is for the place to adopt a characteristic town policy. 
3) The resource endowment of local governments.

The central government has issued many times that characteristic towns should be based on such features as resource endowment, local environment, history and culture, and industrial cluster, and the towns should accelerate the development of leading industries with characteristics and advantages. Zhejiang province stipulates that characteristic towns should be built with a standard which should not be lower than $3 \mathrm{~A}$ scenic areas. The number of $5 \mathrm{~A}$ scenic spots can reflect local environment, historical and cultural characteristics of a place. The more distinctive a place is, the more advantages of applying for a characteristic town it has, thus the local government may be more inclined to adopt the characteristic town policy. In addition, the larger the area of a local jurisdiction, the more resource endowment it may have, and the more likely it is to adopt a characteristic town policy (Zhang, 2017; Zhao, 2015).

Hypothesis 5: The more the number of $5 \mathrm{~A}$ scenic spots in a place, the more likely it is to adopt a characteristic town policy.

Hypothesis 6: The larger the area of a local jurisdiction, the more likely it is to adopt a characteristic town policy.

\subsubsection{External Factors}

As China is a unitary country, superior governments has absolute authority over inferior governments. With the pressure directly from the superior governments, administrative orders from superior governments can be well implemented. Meanwhile, in order not to fall behind in the appraisal of governments at the same level, governments with similar political and economic status will compete to adopt policies under the pressure from governments of the same rank.

Hypothesis 5: If the superior governments launch the characteristic town policy, the superior governments are more likely to adopt characteristic town policy.

Hypothesis 6: For a provincial government, the greater the number of policies adopted by governments at the same level with similar political and economic status, the more likely it is for local government to adopt characteristic town policy.

\subsection{Variable Measurement and Data Sources}

\subsubsection{The Dependent Variable}

The dependent variable in this paper is policy adoption, which means that a provincial government promulgates a characteristic town policy in a year. The variable discussed above is a dichotomous variable. In this case, when a provincial government adopts the characteristic town policy in a certain year, then the value will be 1 , otherwise it will be 0 .

\subsubsection{Independent Variable}

According to the research hypothesis, the scientific nature and availability of data should be taken into account, and the corresponding indicators should be selected to measure independent variables. In addition, the statistical values of economic status, financial status, urbanization rate, and real estate investment 
portion lag one period. The measurement methods of each index and sources are shown in the Table 1 .

\subsubsection{Model Selection}

Since Berry \& Berry introduced the Event History Analysis method (EHA model) into the area of public policy diffusion, it has become a basic research paradigm to explore the influencing factors and mechanisms of policy diffusion with all affecting factors taken into consideration (Berry \& Berry, 1990). This paper employs the event history analysis method to sort out the data according to the "province-year" mode, and builds a database containing "city-year" observation points of 31 provincial administrative units from 2015 to 2019, and uses the Logit model to test and analyze the influence of various factors on the characteristic town policy diffusion.

\subsubsection{Empirical Analysis}

In order to analyze the impacts of internal factors and external factors on the policy diffusion process of characteristic towns, Table 2 reports three EHA models based on logit regression. The model 1 reports internal factors based on logit regression results, while the model 2 reports external factors based on logit regression results. Meanwhile, the model 3 comprehensively considers the implications of internal factors and external factors for policy diffusion of

Table 1. Variables and measurement methods.

\begin{tabular}{|c|c|c|}
\hline Variable Names & Measurement Methods & Data Sources \\
\hline Economic situation & $\begin{array}{l}\text { Annual per capita GDP } \\
\text { (thousands of yuan) }\end{array}$ & $\begin{array}{l}\text { China Statistical } \\
\text { Yearbook }\end{array}$ \\
\hline Financial situation & $\begin{array}{c}\text { Year (expenditure within local budget-revenue } \\
\text { within local budget)/expenditure } \\
\text { within local budget (\%) }\end{array}$ & $\begin{array}{l}\text { China Statistical } \\
\text { Yearbook }\end{array}$ \\
\hline Urbanization rate & $\begin{array}{l}\text { Annual urban population/total number of } \\
\text { population (\%) }\end{array}$ & $\begin{array}{l}\text { China Statistical } \\
\text { Yearbook }\end{array}$ \\
\hline $\begin{array}{l}\text { Real estate } \\
\text { investment ratio }\end{array}$ & $\begin{array}{l}\text { Real estate investment } \div \text { investment } \\
\text { in fixed assets (\%) }\end{array}$ & $\begin{array}{l}\text { China Statistical } \\
\text { Yearbook }\end{array}$ \\
\hline $5 \mathrm{~A}$ scenic spot & The number of $5 \mathrm{~A}$ scenic spot & Statistics from author \\
\hline $\begin{array}{l}\text { Acreage of the } \\
\text { jurisdiction area the }\end{array}$ & $\begin{array}{l}\text { Acreage of the provincial jurisdiction } \\
\text { area }(10,000 \text { square kilometers })\end{array}$ & $\begin{array}{l}\text { China Statistical } \\
\text { Yearbook }\end{array}$ \\
\hline $\begin{array}{l}\text { Pressure from central } \\
\text { governments }\end{array}$ & $\begin{array}{l}\text { Dichotomous variables. With the characteristic } \\
\text { town policy issued by central government for } \\
\text { the first time as the standard, the value will be } \\
0 \text { before the central order is issued, while the } \\
\text { value will be } 1 \text { after the order is issued. }\end{array}$ & $\begin{array}{l}\text { Central } \\
\text { government } \\
\text { website }\end{array}$ \\
\hline $\begin{array}{l}\text { Pressure from } \\
\text { governments at } \\
\text { the same level }\end{array}$ & $\begin{array}{l}\text { In a province, the percentage of provinces } \\
\text { adopting the characteristic town policy (\%) }\end{array}$ & $\begin{array}{l}\text { Provincial } \\
\text { government } \\
\text { websites }\end{array}$ \\
\hline
\end{tabular}


Table 2. Regression analysis based on different factors of Logit model.

\begin{tabular}{|c|c|c|c|}
\hline & Molde1 & Molde2 & Molde3 \\
\hline Economic situation & $\begin{array}{l}1.087^{\star * *} \\
(0.0353)\end{array}$ & & $\begin{array}{l}1.106^{* \star} \\
(0.0447)\end{array}$ \\
\hline Financial situation & $\begin{array}{l}1.046^{*} \\
(0.0257)\end{array}$ & & $\begin{array}{c}1.024 \\
(0.0261)\end{array}$ \\
\hline Urbanization rate & $\begin{array}{c}0.892^{*} \\
(0.0571)\end{array}$ & & $\begin{array}{l}0.831^{* *} \\
(0.0720)\end{array}$ \\
\hline Real estate investment & $\begin{array}{c}1.027 \\
(0.0315)\end{array}$ & & $\begin{array}{c}1.051 \\
(0.0413)\end{array}$ \\
\hline 5A scenic spot & $\begin{array}{c}1.013 \\
(0.0627)\end{array}$ & & $\begin{array}{c}0.974 \\
(0.0631)\end{array}$ \\
\hline $\begin{array}{c}\text { Acreage of the jurisdiction } \\
\text { area the }\end{array}$ & $\begin{array}{c}0.980^{* *} \\
(0.00781)\end{array}$ & & $\begin{array}{l}0.980^{* *} \\
(0.00808)\end{array}$ \\
\hline $\begin{array}{l}\text { Pressure from central } \\
\text { governments }\end{array}$ & & $\begin{array}{c}2.734 \\
(1.734)\end{array}$ & $\begin{array}{l}4.813^{*} \\
(3.953)\end{array}$ \\
\hline $\begin{array}{c}\text { Pressure from governments } \\
\text { at the same level }\end{array}$ & & $\begin{array}{c}1.008 \\
(0.00952)\end{array}$ & $\begin{array}{c}1.004 \\
(0.0128)\end{array}$ \\
\hline Constant & $\begin{array}{c}0.531 \\
(1.665)\end{array}$ & $\begin{array}{l}0.199^{* * *} \\
(0.0922)\end{array}$ & $\begin{array}{c}8.534 \\
(31.78)\end{array}$ \\
\hline Wald $\chi^{2}(\mathrm{df})$ & 10.69 & 6.57 & 15.65 \\
\hline Pseudo- $\mathrm{R}^{2}$ & 0.098 & 0.068 & 0.176 \\
\hline
\end{tabular}

Note: Robust standard errors in parentheses. ${ }^{* * *} \mathrm{p}<0.01,{ }^{* *} \mathrm{p}<0.05,{ }^{*} \mathrm{p}<0.1$.

characteristic towns.

In the Model 1, Hypothesis 1 and Hypothesis 3 are significantly confirmed. When the GDP per capita is above 1\%, it imposes great impacts upon the adoption of characteristic town policy. When the per capita GDP in a province increases by $1000 \mathrm{RMB}$, its advantage of adopting a characteristic town will increase by $8.7 \%$. At the same time, the urbanization rate above $10 \%$ level significantly affects the adoption of the characteristic town policy. When urbanization rises by 1 percentage point in a province, its advantage of adopting a characteristic town will be reduced by $10.8 \%$. Hypothesis 4 and Hypothesis 5 fail to pass the significance test. The possible reasons for the failure are that the small number of $5 \mathrm{~A}$ scenic spots in each province and low proportion of real estate development and investment in the fixed assets of the whole society. Meanwhile, policymakers do not take the number of scenic spots and the proportion of real estate investment as the main factors when they are making decisions. The test results of the financial situation and the areas of jurisdiction are remarkably opposite to Hypothesis 2 and Hypothesis 6, which may be because the provinces with poor financial status tend to adopt policies to obtain the recognition of the central government for more financial support. In addition, the larger the jurisdic- 
tion area of a province is, the bigger the management cost will be and the more prudent it will be about the financial expenditure. Such project as the characteristic town which needs large amounts of capital requires policy adoption in a more cautious way.

In Model 2, the pressure directly from the central government and the pressure from the same level of government are in the same direction predicted by Hypothesis 7 and Hypothesis 8, which fail to pass the significance test, indicating that external pressure will increase the probability of policy adoption. Local governments will integrate internal and external factors to make decisions over the adoption of characteristic town policy.

In Model 3, the per capita GDP, urbanization rate, and jurisdiction area play a stable role in the adoption of characteristic town policy, which is consistent with Model 1 where pressure from superior governments is confirmed at the $10 \%$ level. On the whole, the economic situation, urbanization rate, area of jurisdiction, and central pressure occupy an critical role in the policy diffusion of characteristic towns.

\section{Conclusion}

The landing and changes of the characteristic town policy in China demonstrate apparent diffusion effects, which conforms to the general policy diffusion law and enjoys Chinese characteristics at the same time.

In terms of time, the diffusion of characteristic town policy among provincial governments is correspondent with the classic S-shaped cumulative distribution curve, which can be divided into three stages. First of all, the "pilot zone" in Zhejiang province has embarked on a road integrated with new urbanization with distinctive features and regional characteristic industries. After the promulgation of the national characteristic town policy, the construction of characteristic towns began to spread throughout the country, which leads to the rapid spread of the characteristic town policy. After two years of construction, the policy diffusion rate begins to stabilize and enter the later stage of policy diffusion.

In terms of spatial dimension, the characteristic town policy is initiated by the local government. After approval from the central government, which indicates a certain level of effect, governments at the provincial, municipal, county, and township levels study in depth and follow up the policy. Provincial governments compete with each other to learn from each other. Followers represented by Jiangsu province continuously improve and innovate the policy in accordance with the political and economic conditions in their jurisdictions, contributing to the spread of the characteristic town policy from eastern China to western China.

Among internal and external factors, the economic situation poses a significant impact on the diffusion of characteristic town policy. The better a local economy is, the more likely it is to adopt a characteristic town policy. A higher 
urbanization rate will reduce the possibility of local governments adopting the policy. The larger the area of a province is, the bigger the provincial management cost will be. The more cautious a province is about its fiscal expenditures, and the more prudent of it will be when the province is adopting the characteristic town policy. Against the background of China's unitary system, the central pressure has greatly driven the diffusion of characteristic town policy.

What should be pointed out is that this study still has some shortcomings due to many limitations.

First of all, the research object of this paper is the provincial governments, which is obviously affected by the central government's mandatory influence. The policy innovation diffusion mechanism of the municipal government can be used as the object of further research. Secondly, the paper uses a dichotomy to tell whether the provincial government has adopted the characteristic town policy. Since the specific situation of each local government's policy implementation in the short future, the focus will be on the study of each stage ranging from policy adoption to implementation process and analysis on the achievements of policy implementation.

\section{Conflicts of Interest}

The author declares no conflicts of interest regarding the publication of this paper.

\section{References}

Arbolino, R., Carlucci, F., De Simone, L., Ioppolo, G., \& Yigitcanlar, T. (2018). The Policy Diffusion of Environmental Performance in the European Countries. Ecological Indicators, 89, 130-138. https://doi.org/10.1016/j.ecolind.2018.01.062

Berry, F. S. (1994). Innovation in Public Management: The Adoption of Strategic Planning. Public Administration Review, 54, 322-330. https://doi.org/10.2307/977379

Berry, F. S., \& Berry, W. D. (1990). State Lottery Adoptions as Policy Innovations: An Event History Analysis. American Political Science Review, 84, 395-415. https://doi.org/10.2307/1963526

Brown, L. A., \& Cox, K. R. (1971). Empirical Regularities in the Diffusion of Innovation. Annals of the Association of American Geographers, 61, 551-559. https://doi.org/10.1111/j.1467-8306.1971.tb00806.x

Go, M. H. (2016). Building a Safe State Hybrid Diffusion of Building Code Adoption in American States. The American Review of Public Administration, 46, 713-733. https://doi.org/10.1177/0275074014563827

Li, Y., \& Shang, H. (2020). Service Quality, Perceived Value, and Citizens' ContinuousUse Intention regarding e-Government: Empirical Evidence from China. Information \& Management, 57, 103197. https://doi.org/10.1016/j.im.2019.103197

Nicholson-Crotty, S. (2009). The Politics of Diffusion: Public Policy in the American States. Journal of Politics, 71, 192-205. https://doi.org/10.1017/S0022381608090129

Shang, H. P., Li, W. W., \& Liu, W. (2018). Innovation or Imitation-A Comparison of Performance Evaluation Models in China. Transylvanian Review of Administrative Sciences, 14, 138-154. https://doi.org/10.24193/tras.54E.9 
Walker, J. L. (1969). The Diffusion of Innovations among the American States. The American Political Science Review, 63, 880-899. https://doi.org/10.2307/1954434

Wang, L. Z., \& Pang, R. (2018). Temporal and Spatial Evolution Mechanism and Policy Diffusion Path of China's Public Policy: A Study of the Implementation and Changes of River-Chief System. Chinese Public Administration, No. 5, 63-69.

Weyland, K. (2005). Theories of Policy Diffusion: Lessons from Latin-American Pension Reform. World Politics, 57, 262-295. https://doi.org/10.1353/wp.2005.0019

Zhang, K. (2017). Fiscal Reform as a Part of Reform of Direct Provincial Supervision of County from the Perspective of Policy Diffusion: An Exploratory Analysis Based on Data of 20 Provinces. Journal of Beijing Administration Institute, No. 1, 17-26.

Zhang, Y. L., \& Zhu, X. F. (2018). Multiple Mechanisms of Policy Diffusion in China. Public Management Review, 21, 495-514. https://doi.org/10.1080/14719037.2018.1497695

Zhao, Q. (2015). How Institutional Pressures Affect Innovation Diffusion in Local Government Public Services: The Case of Grid-Based City Management. Journal of Public Administration, 8, 103-119.

Zhong Zheng Think Tank (2019). https://www.sohu.com/a/317391355 801793

Zhou, X. H. (2017). Industrial Transformation and Cultural Rebuilding: The Path of Creation of the Characteristic Town. Nanjing Journal of Social Sciences, No. 4, 12-19.

Zhu, X. F. (2014). Mandate versus Championship: Vertical Government Intervention and Diffusion of Innovation in Public Services in Authoritarian China. Public Management Review, 16, 117-139. https://doi.org/10.1080/14719037.2013.798028

Zhu, X. F., \& Zhang, Y. L. (2019). Diffusion of Marketization Innovation with Administrative Centralization in a Multilevel System: Evidence from China. Journal of Public Administration Research and Theory, 29, 133-150.

https://doi.org/10.1093/jopart/muy034 